\title{
Noninvasive ventilation for pediatric patients under 1 year of age after cardiac surgery
}

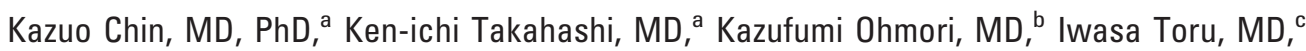

Hisako Matsumoto, MD, PhD, ${ }^{\mathrm{a}, \mathrm{c}}$ Akio Niimi, MD, PhD, ${ }^{a}$ Hiraku Doi, MD, PhD, ${ }^{c}$ Tadashi Ikeda, MD, PhD, ${ }^{b}$

Tatsutoshi Nakahata, MD, PhD, ${ }^{\mathrm{c}}$ Masashi Komeda, MD, PhD, ${ }^{\mathrm{b}}$ and Michiaki Mishima, MD, PhDa, Kyoto, Japan

$\mathrm{A}$

lthough noninvasive positive-pressure ventilation (NPPV) is effective in adults, ${ }^{1,2}$ there are few reports on the use of NPPV in infants. There has been no report on infants who received NPPV after cardiac surgery. ${ }^{3}$ We present the case histories of 2 patients under 1 year of age who had critical respiratory failure with hypercapnia after cardiac surgery and who were successfully treated with NPPV without sedation. ${ }^{4}$

\section{Clinical Summaries}

Patient 1. A 7-month-old female infant (height, $54.1 \mathrm{~cm}$ [-4.5 SD]; weight, $3.8 \mathrm{~kg}$ [-4.1 SD]; human atrial natriuretic peptide level, $291.7 \mathrm{pg} / \mathrm{mL}$; human brain natriuretic peptide level, $169.0 \mathrm{pg} / \mathrm{mL}$ ) with cardiac atrial septal defect, pulmonary hypertension, and right-sided diaphragm elevation underwent closure of the atrial septal defect. On postoperative day (POD) 1, after several hours of continuous positive airway pressure ventilation at $3 \mathrm{~cm}$ $\mathrm{H}_{2} \mathrm{O}$, the arterial oxygen tension $\left(\mathrm{PaCO}_{2}\right)$ was about $55 \mathrm{~mm} \mathrm{Hg}$ and she was extubated. Seven hours after extubation, the $\mathrm{PaCO}_{2}$ rose to $80 \mathrm{~mm} \mathrm{Hg}$, tachypnea was present, and the pulmonary artery pressure increased (Figure 1). We administered NPPV (bilevel positive-pressure ventilation (ResMed, Sydney, Australia), timed mode, inspiratory positive airway pressure (PAP) $7.6 \mathrm{~cm} \mathrm{H}_{2} \mathrm{O}$, expiratory PAP $3.6 \mathrm{~cm} \mathrm{H}_{2} \mathrm{O}$, respiratory rate 30 breaths/min; 4 $\mathrm{L} / \mathrm{min}$ oxygen supply), and the $\mathrm{PaCO}_{2}$ and pulmonary artery pressure decreased (Figure 1). NPPV was administered continuously from PODs 1 to 14. While she was awake and breathing room air on POD 17 without NPPV, the $\mathrm{PaCO}_{2}$ was $52.0 \mathrm{~mm} \mathrm{Hg}, \mathrm{PaO}_{2} 73.3$ $\mathrm{mm} \mathrm{Hg}, \mathrm{pH} 7.366$, and $\mathrm{H}_{2} \mathrm{CO}_{3} 29.1 \mathrm{mmol} / \mathrm{L}$. With NPPV on POD 19 , the transcutaneous $\mathrm{PCO}_{2}\left(\mathrm{TcPCO}_{2}\right)$ fluctuated periodically. Although polysomnography was not performed, such elevations would be due to rapid eye movement sleep-related hypoventilation. The degree of fluctuation was small, and the $\mathrm{TcPCO}_{2}$ did not show an increasing trend. Without NPPV on POD 20, the $\mathrm{TcPCO}_{2}$

From the Departments of Respiratory Medicine, ${ }^{\text {a Cardiovascular Surgery, }}$, and Pediatrics, ${ }^{\mathrm{c}}$ Graduate School of Medicine, Kyoto University, Kyoto, Japan.

Received for publication Jan 31, 2007; revisions received Feb 20, 2007; accepted for publication March 5, 2007.

Address for reprints: Kazuo Chin MD, Department of Respiratory Medicine, Graduate School of Medicine, Kyoto University, Sakyo-Ku, Kyoto, 606-8507, Japan (E-mail: chink@kuhp.kyoto-u.ac.jp).

J Thorac Cardiovasc Surg 2007;134:260-1

$0022-5223 / \$ 32.00$

Copyright @ 2007 by The American Association for Thoracic Surgery doi:10.1016/j.jtcvs.2007.03.002

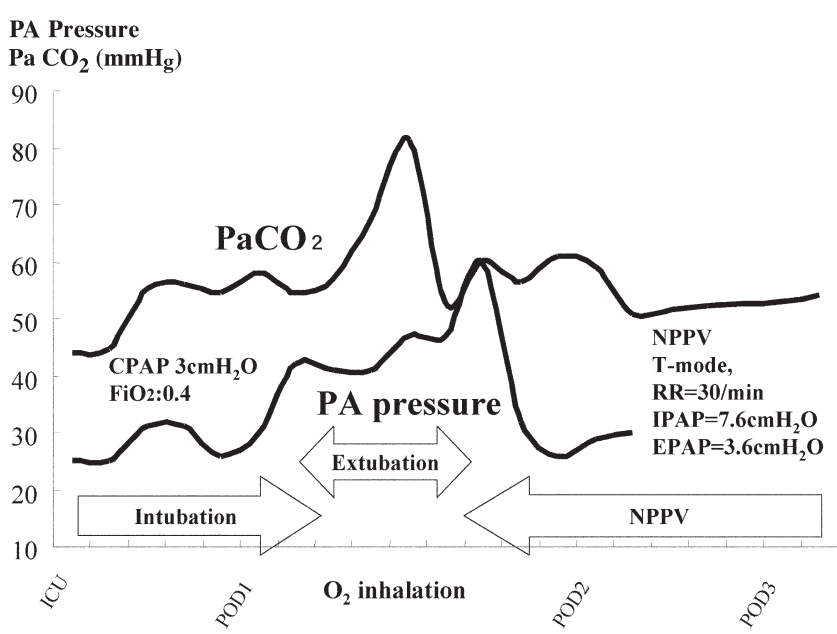

Figure 1. $\mathrm{PaCO}_{2}$ and PA pressure in patient 1 before and after extubation. After several hours of $3 \mathrm{~cm} \mathrm{H} \mathrm{H}_{2} \mathrm{O}$ CPAP, her $\mathrm{PaCO}_{2}$ was about $55 \mathrm{~mm} \mathrm{Hg}$. Seven hours after extubation, her $\mathrm{PaCO}_{2}$ rose to over $80 \mathrm{~mm} \mathrm{Hg}$ and her PA pressure also increased. NPPV was started, and her $\mathrm{PaCO}_{2}$ and $\mathrm{PA}$ pressure improved. $\mathrm{PaCO}_{2}$, Arterial carbon dioxide tension; $P A$, pulmonary artery; $C P A P$, continuous positive airway pressure, $\mathrm{F}_{2} \mathrm{O}_{2}$, inspiratory fraction of oxygen; $N P P V$, noninvasive positive pressure ventilation; $T$-mode, timed mode; $R R$, respiratory rate; IPAP, inspiratory positive airway pressure; $E P A P$, expiratory positive airway pressure; $I C U$, intensive care unit; $P O D$, postoperative day.

fluctuated periodically; however, the $\mathrm{TcPCO}_{2}$ showed an increasing trend and increased to as high as $95 \mathrm{~mm} \mathrm{Hg}$ (Figure 2). We decided to continue NPPV during nighttime hours, and she was discharged on POD 29 using home NPPV. Home NPPV was successfully discontinued after 12 months of NPPV, at which time the $\mathrm{TcPCO}_{2}$ during sleep did not exceed $50 \mathrm{~mm} \mathrm{Hg}$.

Patient 2. A 4-month-old male infant (height, $57.4 \mathrm{~cm} \mathrm{[-2.4}$ $\mathrm{SD}$; weight, $4.39 \mathrm{~kg}$ [-3.2 SD]; human atrial natriuretic peptide level, $1110 \mathrm{pg} / \mathrm{mL}$; human brain natriuretic peptide level, 1180 $\mathrm{pg} / \mathrm{mL}$ ) with a single ventricle underwent right ventricular-pulmonary artery conduit and common atrioventricular valve replacement. He was extubated on POD 3 but was reintubated because of respiratory distress with hypercapnia. On POD 23, while he was extubated, his $\mathrm{TcPCO}_{2}$ showed an increasing trend with fluctuation. We administered NPPV for 5 days (timed mode, inspiratory PAP $7.6 \mathrm{~cm} \mathrm{H}_{2} \mathrm{O}$, expiratory PAP $3.6 \mathrm{~cm} \mathrm{H}_{2} \mathrm{O}$, respiratory rate 30 breaths/min, with air supply), after which his $\mathrm{TcPCO}_{2}$ stabilized. He died of severe hydrocephalus on POD 66. 


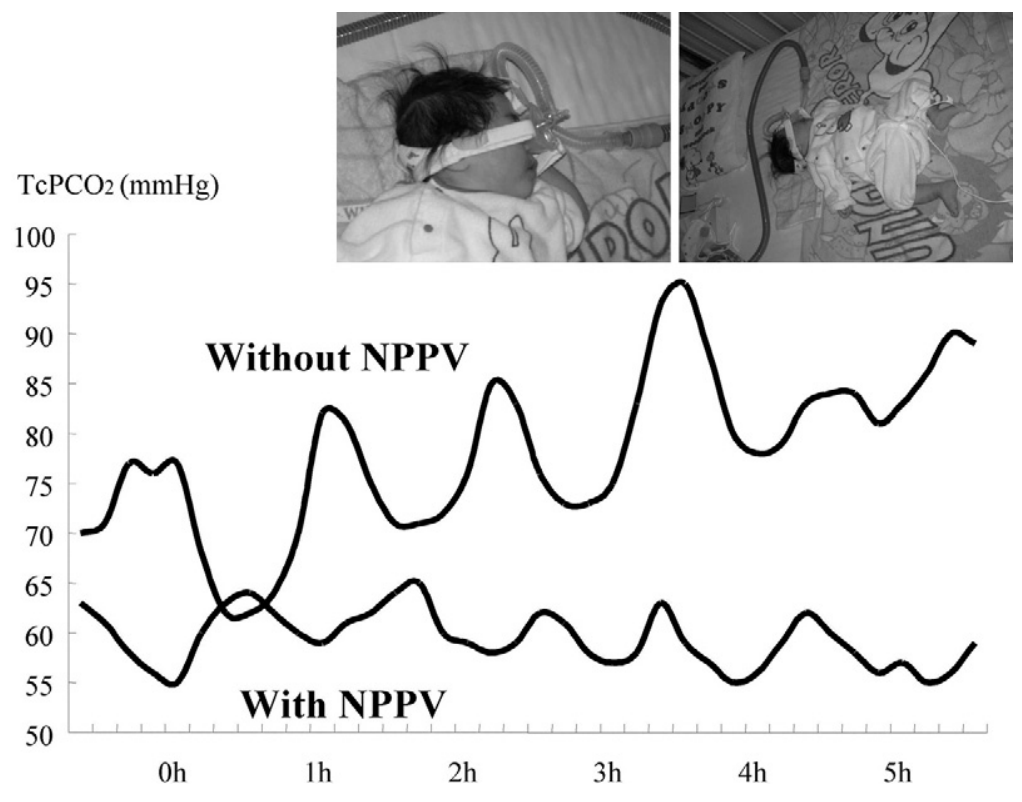

Figure 2. $\mathrm{TcPcO}_{2}$ in patient 1 with or without NPPV. Without NPPV on postoperative day (POD) 20, the $\mathrm{TcPCO}_{2}$ fluctuated periodically and showed an increasing trend. With NPPV on POD 19, the $\mathrm{TcPcO}_{2}$ also fluctuated periodically; however, the degree of fluctuation was small and the $\mathrm{TcPCO}_{2}$ did not show an increasing trend. The patient was believed to have rapid eye movement sleep-related hypoventilation. This demonstrated the effectiveness of NPPV. $\mathrm{TCPCO}_{2}$ Transcutaneous $\mathrm{Pco}_{2} ; \mathrm{NPPV}$, noninvasive positivepressure ventilation.

\section{Discussion}

We presented the case histories of 2 infants having respiratory failure with severe hypercapnia after cardiac surgery. It has been reported that NPPV is suitable for patients with hypercapnia. ${ }^{2,4}$ Therefore, we administered NPPV to our patients. If patient 1 had not received ventilatory support with NPPV, she may have required intubation for several months. NPPV may be useful in patients with respiratory failure under 1 year of age after cardiac surgery, as in patients with respiratory disturbance after undergoing liver transplantation. ${ }^{4}$

We administered NPPV in the timed mode for our infant patients. Essouri and associates ${ }^{3}$ used inspiratory pressure support with positive end-expiratory pressure, the so-called spontaneous mode. We believe that the timed mode is appropriate for infants under 2 years of age whose respiratory rate often becomes greater than 60 breaths/min. Further studies are needed to determine which mode is appropriate for infants under 1 or 2 years.

We have administered NPPV to 20 patients under 2 years of age with respiratory failure, including the current 2 patients and those in our previous report, ${ }^{4}$ and the success rate was $80 \%$ $(16 / 20)$. In the successful cases, the arterial oxygen saturation increased to over $95 \%$ with NPPV and supplemental oxygen within 10 minutes. In the cases in which the treatment failed, the patients were in distress and their arterial oxygen saturation remained below $95 \%$ despite NPPV with $10 \mathrm{~L} / \mathrm{min}$ supplemental oxygen.

We performed nocturnal $\mathrm{TcPCO}_{2}$ monitoring with and without NPPV, which clearly showed the effectiveness of NPPV during sleep. $\mathrm{TcPCO}_{2}$ monitoring during sleep with and without NPPV may be useful for determining whether NPPV is necessary during sleep in infants.

Most infants with diaphragmatic paralysis recover over the next several months. ${ }^{5}$ However, surgical plication of the diaphragm is necessary in some cases. Expectant management is generally advocated for at least 2 months before performing surgical plication. ${ }^{5}$ The present cases suggest that NPPV may obviate the need for surgical plication, even in infants who have undergone cardiac surgery.

Considering the usefulness and disadvantages of NPPV, ${ }^{1}$ NPPV may be effective in infants who have respiratory failure after cardiac surgery.

\section{References}

1. British Thoracic Society Standards of Care Committee. Non-invasive ventilation in acute respiratory failure. Thorax. 2002;57:192-211.

2. Tokuda Y, Matsumoto M, Sugita T, Nshizawa J, Matsuyama K, Yoshida K, et al. Bilateral diaphragmatic paralysis after aortic surgery with topical hypothermia: ventilatory assistance by means of nasal mask bilevel positive pressure. J Thorac Cardiovasc Surg. 2003;125:1158-9.

3. Essouri S, Chevret L, Durand P, Haas V, Fauroux B, Devictor D. Noninvasive positive pressure ventilation: five years of experience in a pediatric intensive care unit. Pediatr Crit Care Med. 2006; 7:329-34.

4. Chin K, Uemoto S, Takahashi K, Egawa H, Kasahara M, Fujimoto Y, et al. Noninvasive ventilation for pediatric patients including those under 1-year-old undergoing liver transplantation. Liver Transplant. 2005;11:188-95.

5. Mathew OP. Regulation of breathing in neuromuscular diseases: Mathew OP, editor. Respiratory control and disorders in the newborn. Lung biology in health and disease. Volume 173. New York: Marcel Dekker; 2003. p.409-25. 